\title{
Magnetic signatures of alkaline rocks and gabbros from the Ponta Grossa Arch, southern Brazil
}

Vinicius Antunes Ferreira da Silva ${ }^{1}$, Francisco José Fonseca Ferreira ${ }^{1}$, ${ }^{1}$ Laboratory for Research in Applied Geophysics, Department of Geology, Federal University of Paraná

Copyright 2021, SBGf - Sociedade Brasileira de Geofísica

This paper was prepared for presentation during the $17^{\text {th }}$ International Congress of the Brazilian Geophysical Society held in Rio de Janeiro, Brazil, 16-19 August 2021.

Contents of this paper were reviewed by the Technical Committee of the $17^{\text {th }}$ International Congress of the Brazilian Geophysical Society and do not necessarily represent any position of the SBGf, its officers or members. Electronic reproduction or storage of any part of this paper for commercial purposes without the written consent storage of any part of this paper for commercial
of the Brazilian Geophysical Society is prohibited.

\section{Abstract}

We present airborne magnetic signatures of some igneous suites from the Ponta Grossa Arch Alkaline Province (southern Brazil), namely: Bairro da Cruz and Tunas complexes and José Fernandes Gabbro. We applied magnetic susceptibility 3D inversions using the total magnetic anomaly data alongside its analytic signal of the vertical integral and the vertical integral of the analytic signal for the Bairro da Cruz and Tunas complexes, and the José Fernandes Gabbro, which present dipolar anomalies with normal polarity. Our results were consistent with the geophysical and geological responses of these bodies and can contribute to the understanding of magnetic signatures of alkaline provinces in Brazil.

\section{Introduction}

The Ponta Grossa Arch (PGA) is an uplifted domain located in southern Brazil (Fig. 1). This arch hosts both alkaline and carbonatite-alkaline intrusions and it was labeled the Ponta Grossa Arch Alkaline Province (PGAAP) by Almeida (1983). Most of this province is situated between the southern parts of the Guapiara and São Jerônimo-Curiúva magnetic lineaments (Ferreira 1982). Alkaline intrusions have been recognized and detailed in different scales by airborne magnetic surveys. These surveys contribute to a variety of geological and geophysical interpretations. For example, aeromagnetic maps aid the interpreter in verifying anomalies that coincide with outcropping alkaline intrusions, or even those with no surface expression, as well as to verify possible structural control on such intrusions (e.g., Ferreira and Algarte 1979). Marangoni and Mantovani (2013) characterized the state-of-the-art magnetic and gravity signatures in the PGAAP and other alkaline provinces in Brazil. However, these authors have not reported geophysical signatures of all the bodies from the PGAAP and used previous and lower-resolution aerogeophysical data (flight lines spaced with $1 \mathrm{~km}$ or more). High-resolution aeromagnetic datasets were analyzed to assess the pattern of anomalies over the study area and then comparing with previous studies.

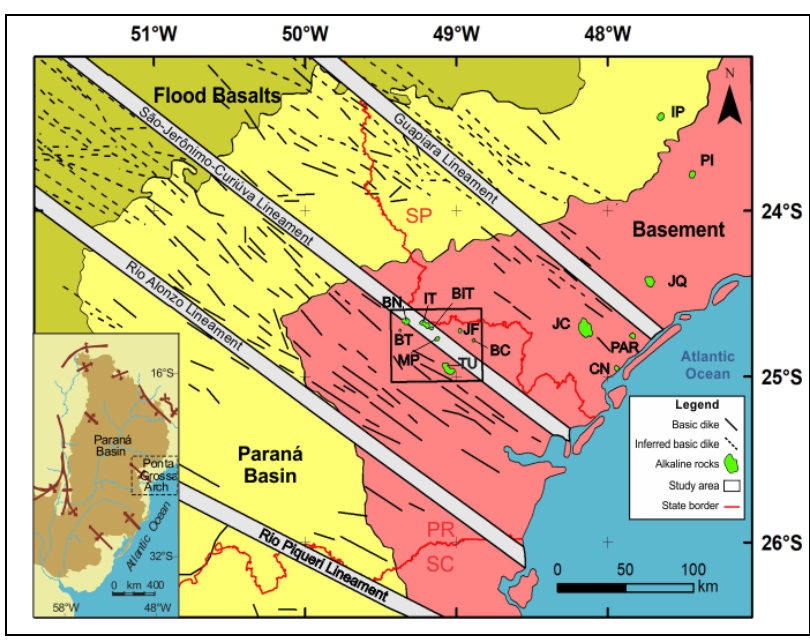

Figure 1 - Sketch map of the Ponta Grossa Arch Alkaline Province (modified from Ruberti et al. 2005; Gomes et al. 2018). Alkaline complexes: Bairro da Cruz (BC), Barra do Itapirapuã (BIT), Banhadão (BN), Barra do Teixeira (BT), Cananéia (CN), Ipanema (IP), Itapirapuã (IT), Jacupiranga (JC), José Fernandes (JF), Juquiá (JQ), Mato Preto (MP), Pariquera-Açu (PAR), Piedade (PI), and Tunas (TU). States: São Paulo (SP), Paraná (PR), and Santa Catarina (SC). See geological context in Silva and Ferreira (2021).

\section{Material and Methods}

The study area was delimited by UTM zone $22 \mathrm{~J}$ coordinates $655,000 \mathrm{~m}-720,000 \mathrm{~m}$ and 7,280,000 m $7,230,000 \mathrm{~m}$, comprising partial regions from the geological maps of Cerro Azul (Brumatti and Almeida 2014) and Apiaí (Morais et al. 2012) (Figs. 1 and 2). These 1:100,000-scale maps were used to discuss the geophysical data in association with the mapped geology. Magnetic data were provided by the Geological Survey of Brazil - CPRM (2011) from the Paraná-Santa Catarina Project (PR-SC). North-south oriented flight lines were spaced $500 \mathrm{~m}$ apart. The data were acquired at a terrain clearance of $100 \mathrm{~m}$. The total magnetic anomaly (TMA) data were interpolated onto a $100 \mathrm{~m}$ grid cell-size, which represents $1 / 5$ of the spacing between lines, using the minimum curvature algorithm. These quantities are treated as if they were reduced to the pole allowing the 3D magnetic susceptibility algorithm inversion developed by $\mathrm{Li}$ and Oldenburg (1996), and the inversion algorithm used considers only induced magnetization. Although there is this inconsistency, both analytic signal of the vertical integral (ASVI) and vertical integral of the analytic signal (VIAS), proposed by Paine et al. (2001), lead to interpretable results being appropriate for isolated or 
multiple sources as well. The complexes that showed a significant magnetic response, i.e., Bairro da Cruz, José Fernandes, and Tunas, were 3D unconstrained inverse modeled to obtain an estimate of the distribution of their magnetic susceptibilities and depth of emplacement. Inversions were applied in the TMA, VIAS-TMA, and ASVI-TMA grids. The RTP parameters for each modeled body were described in Silva \& Ferreira (2021). The RTP processing assumes that remanent magnetization is parallel to the current inducing field direction, and it may introduce additional artifacts into the data. This technique can turn the inversion algorithms ineffective, which was our case, where a significant number of small bodies (artifacts) were created, and, therefore, we decided not to represent this model in this work.

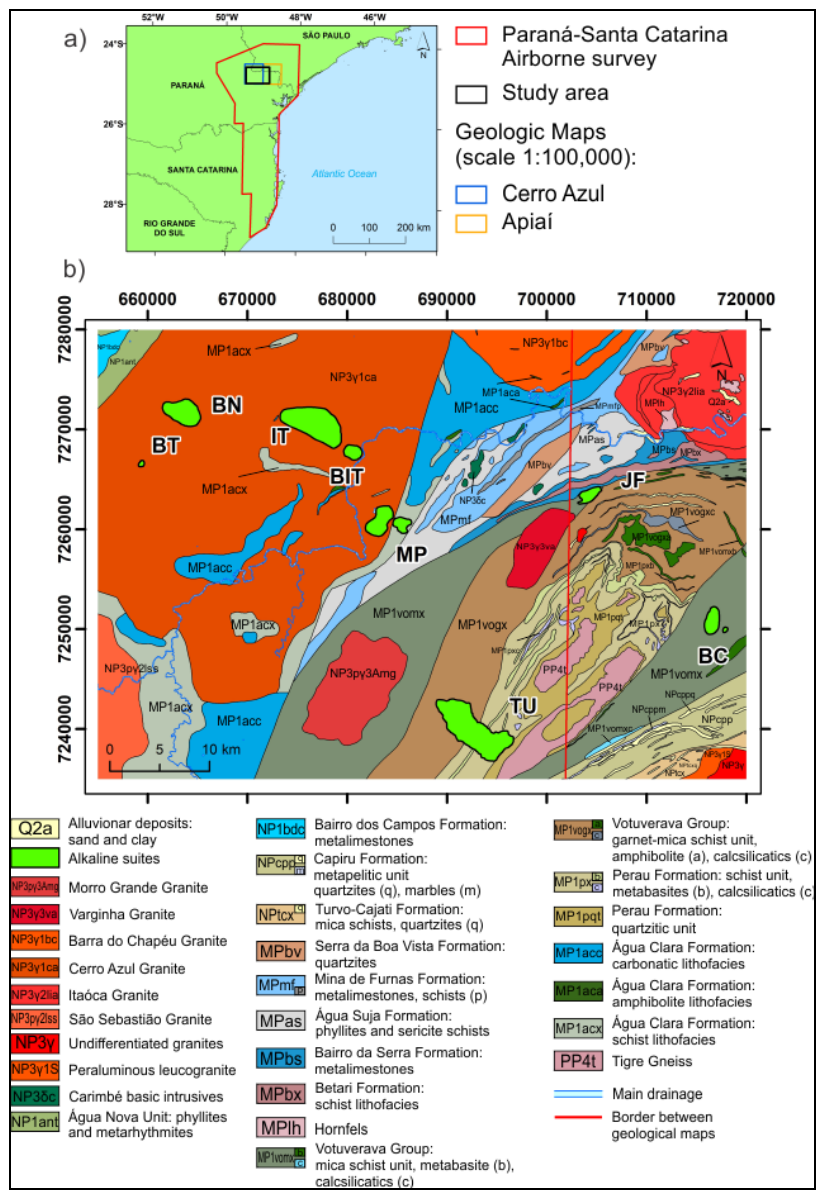

Figure 2 - Location of study area within airborne geophysical survey and geological maps used in this work (a). Simplified geological map for the study area based on Cerro Azul (Brumatti and Almeida 2014) and Apiai (Morais et al. 2012) maps (b). Alkaline complexes: Bairro da Cruz (BC), Barra do Itapirapuã (BIT), Banhadão (BN), Barra do Teixeira (BT), Itapirapuã (IT), José Fernandes (JF), Mato Preto (MP), and Tunas (TU).

\section{Results and Discussion}

\section{Magnetic anomaly of the study area}

Total magnetic anomaly values presented a peak-to-peak amplitude approximately to $2100 \mathrm{nT}$ (Fig. 3). No significant representation of classical dipolar anomalies was observed for IT, BIT, BN, BT, and MP igneous rocks even when TMA data were interpolated in a rectangular area around the location of the intrusions. This behavior can be explained by the common lack of strong magnetization (Airo 2015) and the petrography of these rock types. It should be noted that the Barra do Itapirapuã (BIT) and the Mato Preto (MP) complexes did not produce circular magnetic anomalies or any distinctive magnetic signature, unlike other alkalic-carbonatitic complexes cited in the literature (Airo 2015). The dipolar anomaly of Bairro da Cruz Complex could be attributed to the presence of coarse olivine-gabbros (Hama et al. 1977), which is one of the most ferromagnetic igneous rocks (Clark 1999). The same could be said for the José Fernandes Gabbro, an intrusion with a strong magnetic response that was even detected in lower quality airborne survey datasets (Ferreira and Algarte 1979). Linear magnetic anomalies in the NW-SE direction reflect diabase dikes, which are common in the context of the PGA (Ferreira 1982; Brumatti and Almeida 2014).

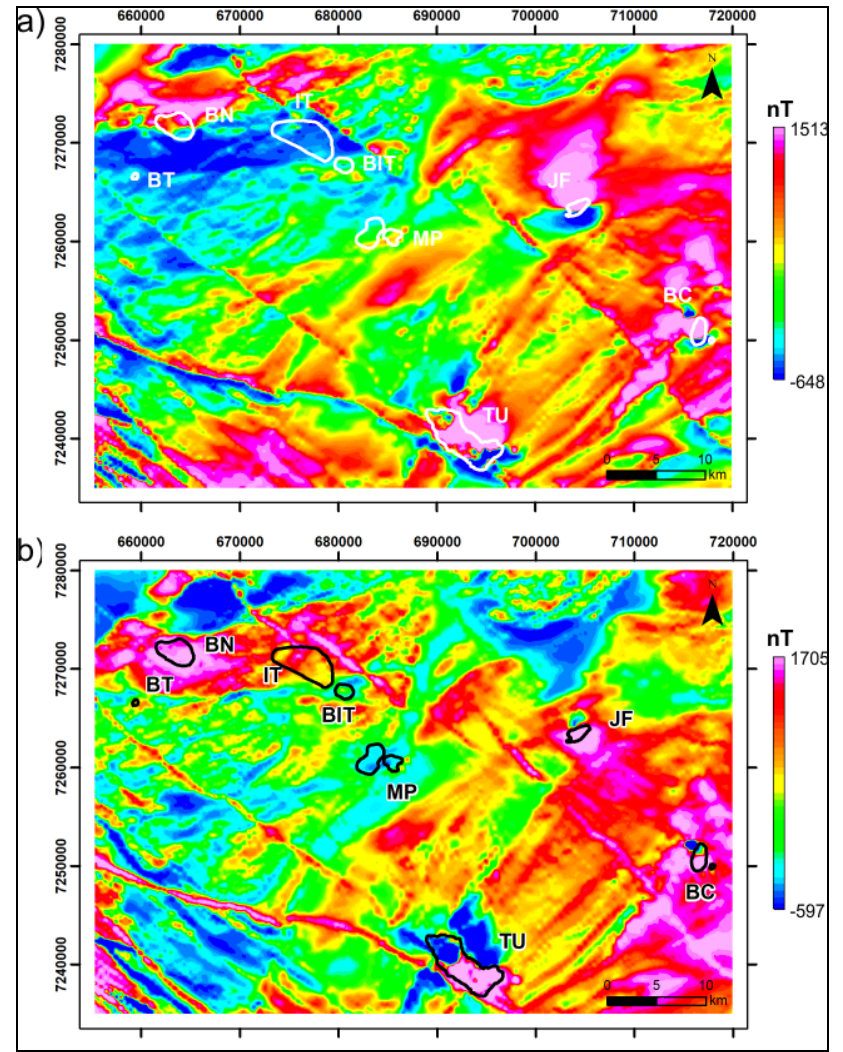

Figure 3 - TMA map of the study area (a) and its reduction to the pole (RTP) (b). Thick white (a) and black (b) lines represent the alkaline complexes: Bairro da Cruz (BC), Barra do Itapirapuã (BIT), Banhadão (BN), Barra do Teixeira (BT), Itapirapuã (IT), José Fernandes (JF), Mato Preto (MP), and Tunas (TU).

\section{Inversions}

The intrusions that presented a significant magnetic response were inversely modeled to assess their magnetic susceptibilities and depths. TMA, ASVI-TMA, and VIAS-TMA grids for Bairro da Cruz, José Fernandes, and Tunas were illustrated to compare the magnetic 
susceptibility model with each occurrence. It is known that diabase dikes in the area can carry remanence and therefore could influence the response for the igneous bodies. However, Raposo \& Ernesto (1995) demonstrated that the vast majority of dikes in the PGA have remanent magnetization with normal polarity. Furthermore, TMA grids of Bairro da Cruz (Fig. 4a), José Fernandes (Fig. 6a), and Tunas (Fig. 8a) showed positive anomalies in their north lobes while the negatives concentrated over their southern portions. This is in good agreement with induced magnetic responses for bodies located in the earth's southern hemisphere that are not significantly affected by remanence.

\section{Bairro da Cruz Complex}

Figure 4a illustrates magnetic values around $-530 \mathrm{nT}$ for the negative lobe of BC anomaly and over $1260 \mathrm{nT}$ in the positive one (peak-to-peak amplitude equal to $1790 \mathrm{nT}$ ). The reduced to the pole anomaly was not located in the center of the outcropped Bairro da Cruz borders (Fig. 4b). Better results were found for the ASVI and VIAS of TMA data (Fig. 4c and 4d, respectively). No significant differences were found between these two methods. Moreover, none of the maps resulted in an appropriate response for the eastern body of Bairro da Cruz, certainly due to its restricted dimensions when compared to the spatial resolution of the grid $(100 \mathrm{~m})$.

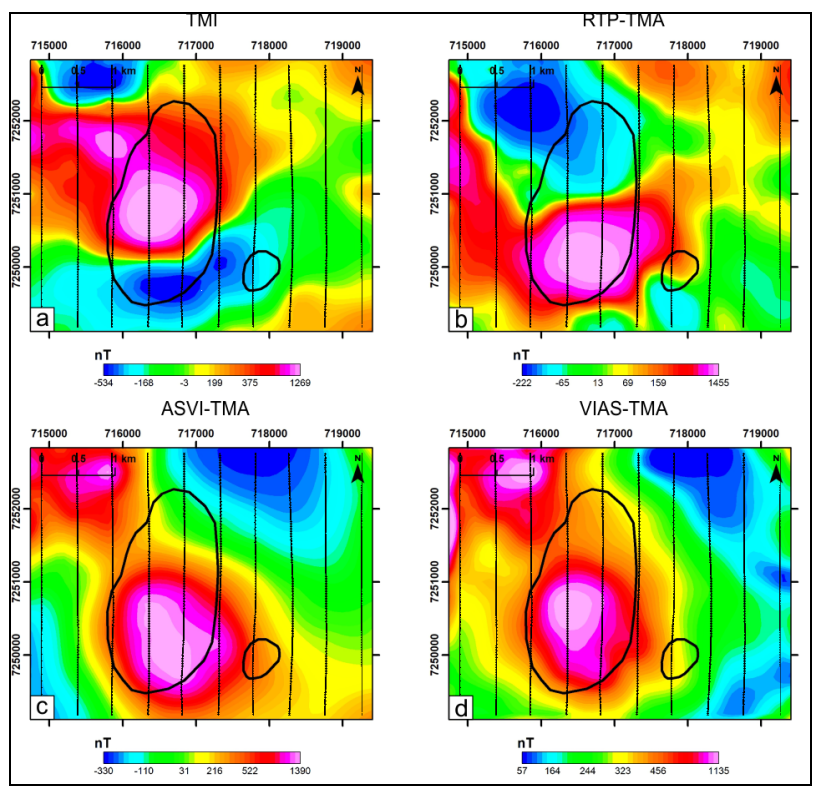

Figure 4 - Magnetic responses of Bairro da Cruz Complex (black polygons): a) Total magnetic anomaly (TMA), b) TMA reduced to the pole (RTP-TMA), c) Analytic signal of the vertical integral of TMA (ASVI-TMA) and d) Vertical integral of the analytic signal of TMA (VIAS-TMA). N-S oriented black lines are the airborne survey flight lines.

Inversions revealed that the contrasts of apparent magnetic susceptibility were similar (Fig. 5). The TMA model created several bodies and no significant correlation was found with the outcropped surface. The ASVI-TMA and VIAS-TMA inversions displayed ellipseshaped features with magnetic susceptibility distribution more elongated in the depth axis. All the models have illustrated susceptibilities inside the range for gabbros, i.e., $3.10^{-4}$ to $3.10^{-1}$ Slu (Clark 1997). Negative values of magnetic susceptibility were situated above -1 , which can be explained by diamagnetic minerals (e.g., quartz) in the meta-arenites and quartzites present in the country rock of Bairro da Cruz, Mica schists unit. However, phonolite magnetic susceptibilities $\left(10^{-5}\right.$ to $10^{-3}$ Slu, Clark 1997) were not successfully represented in the modeling of Figure 5, probably due to the weakly magnetic of this rock type. Altitudes for all the susceptibility models were situated between 750 and $-1750 \mathrm{~m}$. In summary, these results suggest that the Bairro da Cruz could have a thickness of around $2.5 \mathrm{~km}$ reaching a depth of more than $1.5 \mathrm{~km}$ below the Mean Sea Level.

\section{José Fernandes Gabbro}

It can be seen that a magnetic dipole with normal polarity is presented for the José Fernandes Gabbro (Fig. 6a). This result reflects those of Ferreira and Algarte (1979) and Almeida (2016), who also found a similar anomaly for this body. The RTP data (Fig. 6b) displayed amplitudes around $1600 \mathrm{nT}$ while it has positioned the center of the anomaly in the western portion of the geological body while the ASVI-TMA and VIAS-TMA (Fig. 6c, d) created two strong anomalies located near the center of the gabbro. None of the models displayed anomalies with the same NE-trend observed for the outcropped gabbro. The magnetic susceptibility inversion models (Fig. 7) illustrated values between 0 and 0.220 Slu which is consistent with gabbros results from Clark (1997). JF is emplaced in metasedimentary rocks (Morais et al. 2012) and, thus, values of susceptibility below or close to zero could be attributed to those rock types. The models were situated between 750 and $-1500 \mathrm{~m}$ of altitude, thus, suggesting thickness for the causative sources of around $2000 \mathrm{~m}$. A note of caution is due here since there is no magnetic data available that could support better approximations for the distribution of susceptibility.

\section{Tunas Complex}

It can be observed from the total magnetic anomaly data (Fig. 8a) that positive values in the north and low values in the south of the area may correspond to the mapped Tunas geology. However, it is in the southeastern portion of this alkaline complex that a dipole anomaly with more than $1 \mathrm{~km}$ of extension could be visualized. TMA values were situated in the -650 and $1510 \mathrm{nT}$ interval (peak-topeak amplitude equal to $2160 \mathrm{nT}$ ). RTP, ASVI, and VIAS applied to the TMA data (Fig. 8b, c, and d, respectively) have positioned a strong anomaly over the southeastern area of Tunas massif with maximum values around 1600 $\mathrm{nT}$ and up to $3000 \mathrm{nT}$ for the VIAS-TMA image (Fig. 8d). This result may be explained by the fact that the VIAS technique may cause significant amplification of lowfrequency components of data, which is a drawback of this method pointed out by Paine et al. (2001). Distribution models of contrast of apparent magnetic susceptibility (Fig. 9) demonstrated an NW-trend. This finding is consistent with that of Brumatti et al. (2015) who mapped Tunas. However, our results were not very encouraging since they created a significant quantity of bodies for the TMA data while ASVI and VIAS do not 


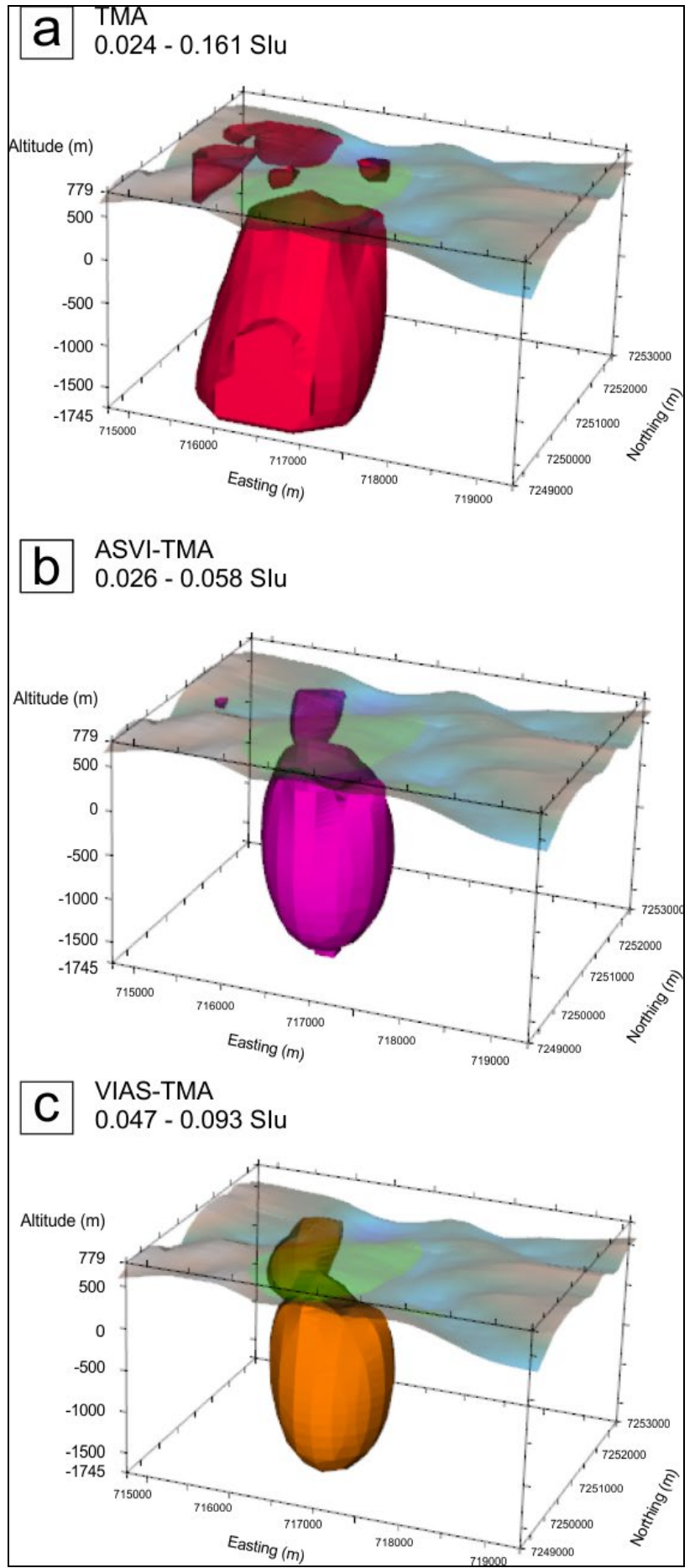

Figure 5 - Contrast of apparent magnetic susceptibility distribution in $3 D$ models for each type of Bairro da Cruz gridded data described in Figure 4 (except for the RTPTMA grid). Models were cut in an arbitrary threshold value (displayed on the image) to create a better representation of the surface geology. Altitudes are GPS altitudes and zero values correspond to the Mean Sea Level (MSL). The blue and brown colored grid over the top represents the Digital Terrain Model (DTM) for the area, which ranges from 795 to $279 \mathrm{~m}$. The green polygon represents the Bairro da Cruz geologic surface boundaries.

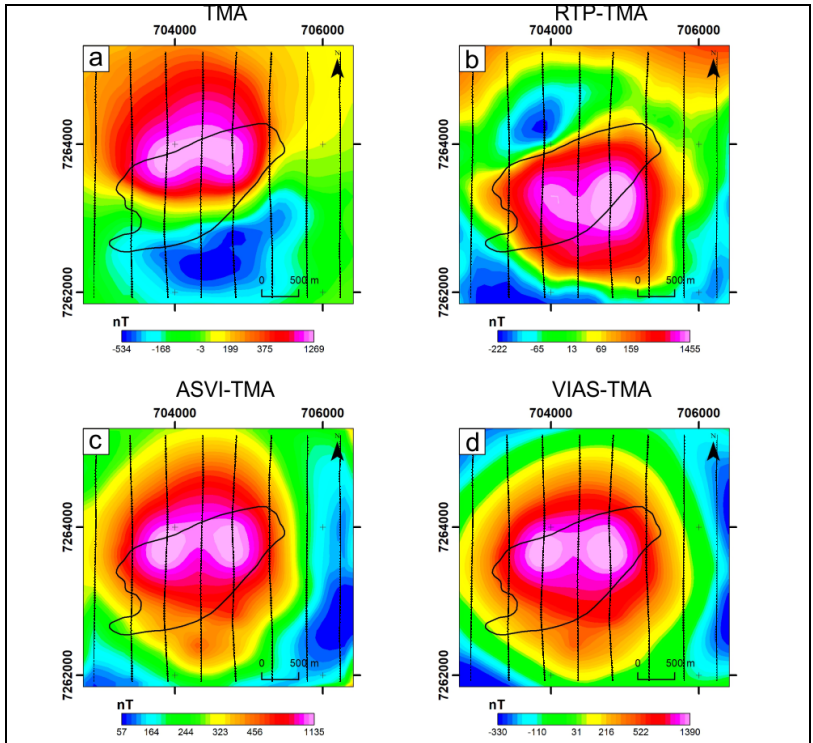

Figure 6 - Magnetic responses of José Fernandes Gabbro (black polygon): a) Total magnetic anomaly (TMA), b) TMA reduced to the pole (RTP-TMA), c) Analytic signal of the vertical integral of TMA (ASVI-TMA) and d) Vertical integral of the analytic signal of TMA (VIAS-TMA). N-S oriented black lines are the airborne survey flight lines.

correspond to the outcropped geology of a single intrusion. The values were situated over 0.02 to 0.25 Slu. Comparison of these results with those of other studies related to other alkaline complexes in Brazil suggest similarities, such as Jacupiranga (0.001 to $0.161 \mathrm{Slu}$ ), Juquiá (0.048 Slu), Araxá (maximum of 0.234 Slu), and Catalão I (0.17 Siu) (see references in Silva \& Ferreira 2021). The largest axis of Tunas models had $6000 \mathrm{~m}$ while its minor had $2500 \mathrm{~m}$. The contrast of apparent magnetic susceptibility models had altitudes between 1000 and $-2500 \mathrm{~m}$. This result is similar to that of Rugenski (2006), who reported a depth of around $3000 \mathrm{~m}$ for the bottom of this body using $2.5 \mathrm{D}$ modeling.

\section{Conclusions}

High-resolution airborne geophysical data provides a powerful component for geologic interpretation when the rocks of interest did not have borehole data or access to their outcropped area is difficult. Prior works have documented geophysical evaluation of alkaline provinces in Brazil. However, these studies have been based on low resolution aeromagnetic data. In this work, we characterized the magnetic responses of the Ponta Grossa Arch Alkaline Province, whose extent has been targeted to mineral exploration for several decades. Modeling showed good agreement with magnetic susceptibilities values of alkaline rocks and gabbros reported in the literature, even though the shape and geometry of the PGAAP rocks could not be representative of the known geology. Further research should be carried out to establish the magnetization vector from the rocks modeled in this study as well as to confirm the intensity of remanent magnetization in those to assist in constrain inversions. 


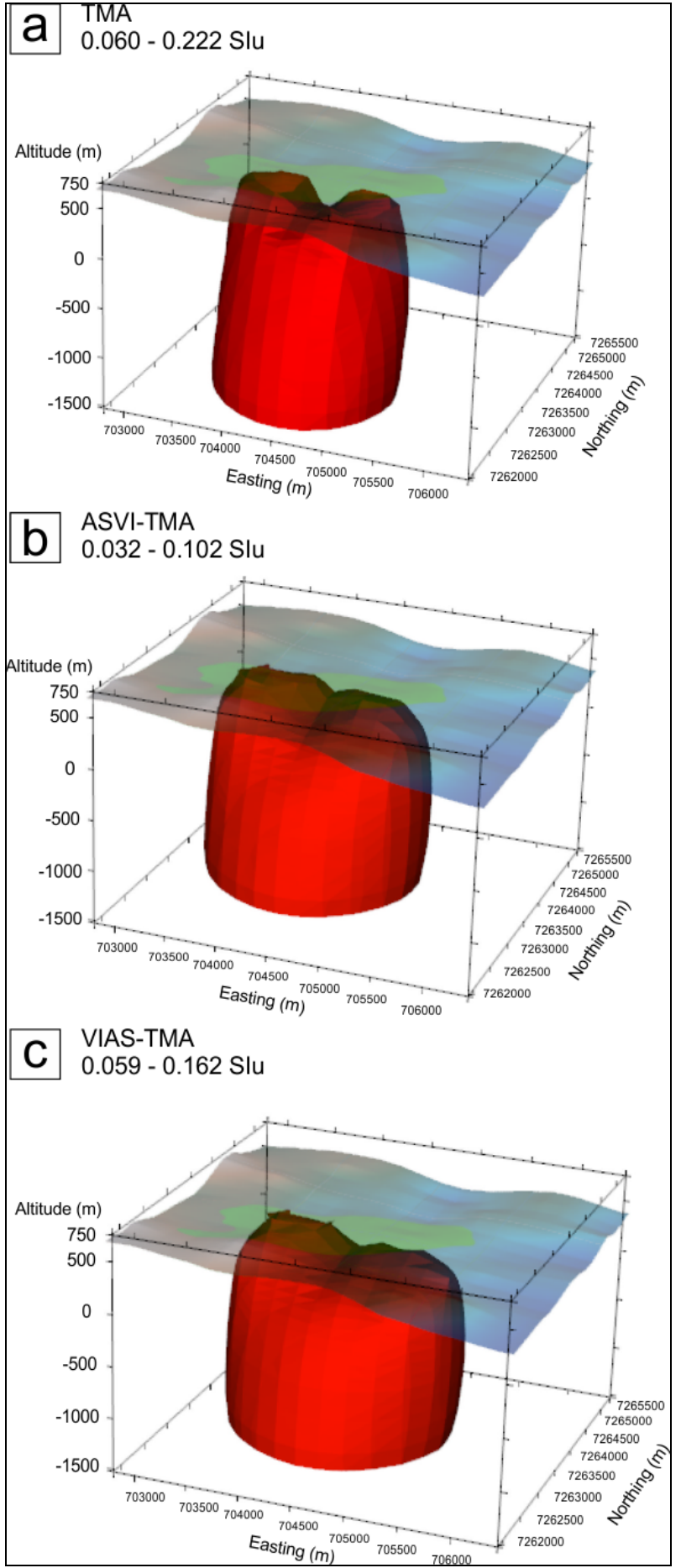

Figure 7 - Contrast of apparent magnetic susceptibility distribution in $3 D$ models for each type of José Fernandes gridded data described in Figure 6 (except for the RTPTMA grid). Models were cut in an arbitrary threshold value (displayed on the image) to create a better representation of the surface geology. Altitudes are GPS altitudes and zero values correspond to the Mean Sea Level (MSL). The blue and brown colored grid over the top represents the Digital Terrain Model (DTM) for the area, which ranges from 717 to $320 \mathrm{~m}$. The green polygon represents the José Fernandes Gabbro geologic surface boundaries.

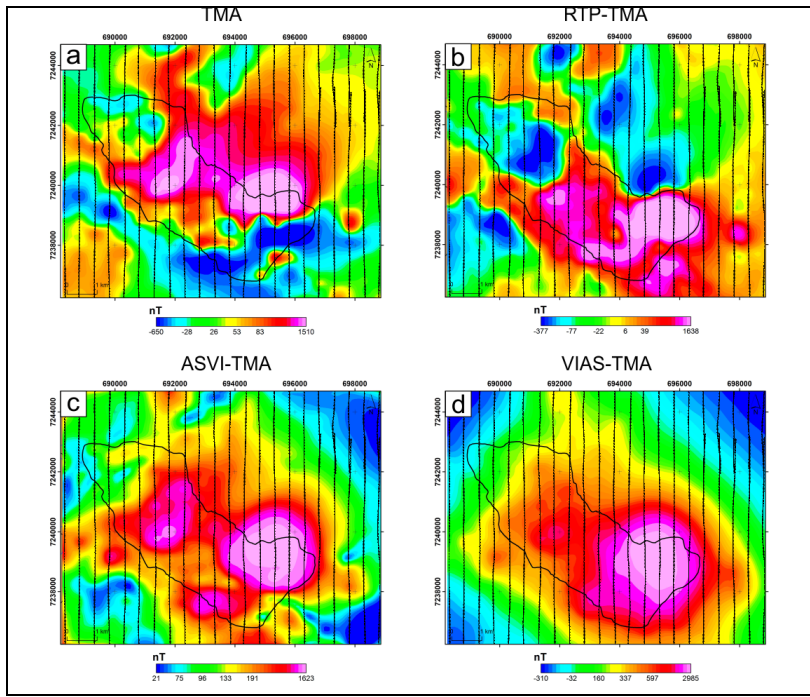

Figure 8 - Magnetic responses of Tunas Complex (black polygon): a) Total magnetic anomaly (TMA), b) TMA reduced to the pole (RTP-TMA), c) Analytic signal of the vertical integral of TMA (ASVI-TMA) and d) Vertical integral of the analytic signal of TMA (VIAS-TMA). N-S oriented black lines are the airborne survey flight lines.

\section{Acknowledgments}

We thank the Geological Survey of Brazil (CPRM) for providing the airborne geophysical data. F.J.F. Ferreira was supported in this research by the National Council for Scientific and Technological Development (CNPq, Brazil) (contract 303826/2018-5).

\section{References}

AIRO M. 2015. Geophysical signatures of mineral deposit types - synopsis. In: Airo M. (ed.) Geophysical signatures of mineral deposit types. Espoo, Geological Survey of Finland, Special Paper, 58, p. 9-70.

ALMEIDA F.F.M. 1983. Relações tectônicas das rochas alcalinas mesozoicas da região meridional da plataforma sul-americana. Revista Brasileira de Geociências, 13:139-158.

ALMEIDA V.V. 2016. Petrologia do Gabro José Fernandes e sua relação temporal com o magmatismo mesozoico toleítico e alcalino no Arco de Ponta Grossa. PhD Thesis, University of São Paulo, Brazil. (In Portuguese).

BRUMATTI M. \& ALMEIDA V.V. 2014. Rochas Alcalinas: Áreas de Registro, Iguape e Cerro Azul. Anexo III: Atualização da cartografia geológica da Folha Cerro Azul SG.22-X-B-IV. Estados de São Paulo e Paraná, escala 1:100000. São Paulo, Geological Survey of Brazil.

BRUMATTI M., ALMEIDA V.V., LOPES A.P., CAMPOS F.F., PERROTTA M.M., MENDES D., PINTO L.G.R., PALMEIRA L.C.M. 2015. Metalogenia das províncias minerais do Brasil: rochas alcalinas da porção meridional do cinturão Ribeira, estados de São Paulo e Paraná. CPRM, Informe de Recursos Minerais, Série Províncias Minerais do Brasil, 6:1-79. 
CLARK D.A. 1997. Magnetic petrophysics and magnetic petrology: aids to geological interpretation of magnetic surveys. AGSO Journal of Australian Geology and Geophysics, 17(2):83-103.

CLARK D.A. 1999. Magnetic petrology of igneous intrusions: implications for exploration and magnetic interpretation. Exploration Geophysics, 30:5-26.

CPRM - Geological Survey of Brazil. 2011. Projeto aerogeofísico Paraná-Santa Catarina Volume I. Lasa Prospecções, $326 \mathrm{p}$.

FERREIRA F.J.F. \& ALGARTE J.P. 1979. O comportamento aeromagnetométrico-cintilométrico das principais rochas alcalinas dos Estados de São Paulo e Paraná. In: Simpósio Regional de Geologia, 2, Rio Claro. Proceedings, v. 2, p. 195-208.

FERREIRA F.J.F. 1982. Aeromagnetic and geological data integration: configuration and tectonic evolution of the Ponta Grossa Arch. Master's Thesis. University of São Paulo, Brazil. (In Portuguese).

GOMES C.B., AZZONE R.G., RUBERTI E., VASCONCELOS P.M., SATO K., ROJAS G.E.E. 2018. New age determinations for the Banhadão and Itapirapuã complexes in the Ribeira Valley, southern Brazil. Brazilian Journal of Geology, 48:1-12.

HAMA M., ALGARTE J.P., PAIVA I.P., RODRIGUES J.C. 1977. Idades K/Ar do maciço alcalino do Banhadão e do complexo Bairro da Cruz. In: Simpósio Regional de Geologia, 1, São Paulo. Proceedings, v. 1, p. 170-178.

LI Y. \& OLDENBURG D.W. 1996. 3-D Inversion of Magnetic Data. Geophysics, 61:394-408.

MARANGONI Y.R. and MANTOVANI M.S.M. 2013. Geophysical signatures of the alkaline intrusions bordering the Paraná Basin. Journal of South American Earth Sciences, 41:83-89.

MORAIS S.M. et al. 2012. Mapa geológico da Folha Apiaí, escala 1:100000. Geological Survey of Brazil.

PAINE J. \& HAEDERLE M. FLIS M. 2001. Using transformed TMI data to invert for remanently magnetised bodies. Exploration Geophysics, 32(3/4): 238-242.

RAPOSO M.I.B. \& ERNESTO M. 1995. An Early Cretaceous paleomagnetic pole from Ponta Grossa dikes (Brazil): implications for the South American Mesozoic apparent polar wander path. Journal of Geophysical Research - Solid Earth, 100(B10):20095-20109.

RUBERTI E., GOMES C.B., COMIN-CHIARAMONTI P. 2005. The alkaline magmatism from the Ponta Grossa Arch. In: Comin-Chiaramonti P. \& Gomes C.B. (eds.). Mesozoic to Cenozoic alkaline magmatism in the Brazilian Platform. São Paulo, EdUSP/Fapesp, p. 473522.

RUGENSKI A. 2006. Investigação geofísica dos complexos alcalinos do sul e sudeste do Brasil. PhD thesis, University of São Paulo, Brazil. (In Portuguese).
SILVA V.A.F. \& FERREIRA F.J.F. 2021. Magnetic and radiometric signatures of alkaline rocks and gabbros from the Ponta Grossa Arch, southeastern Paraná Basin, Brazil. Brazilian Journal of Geology (submitted).

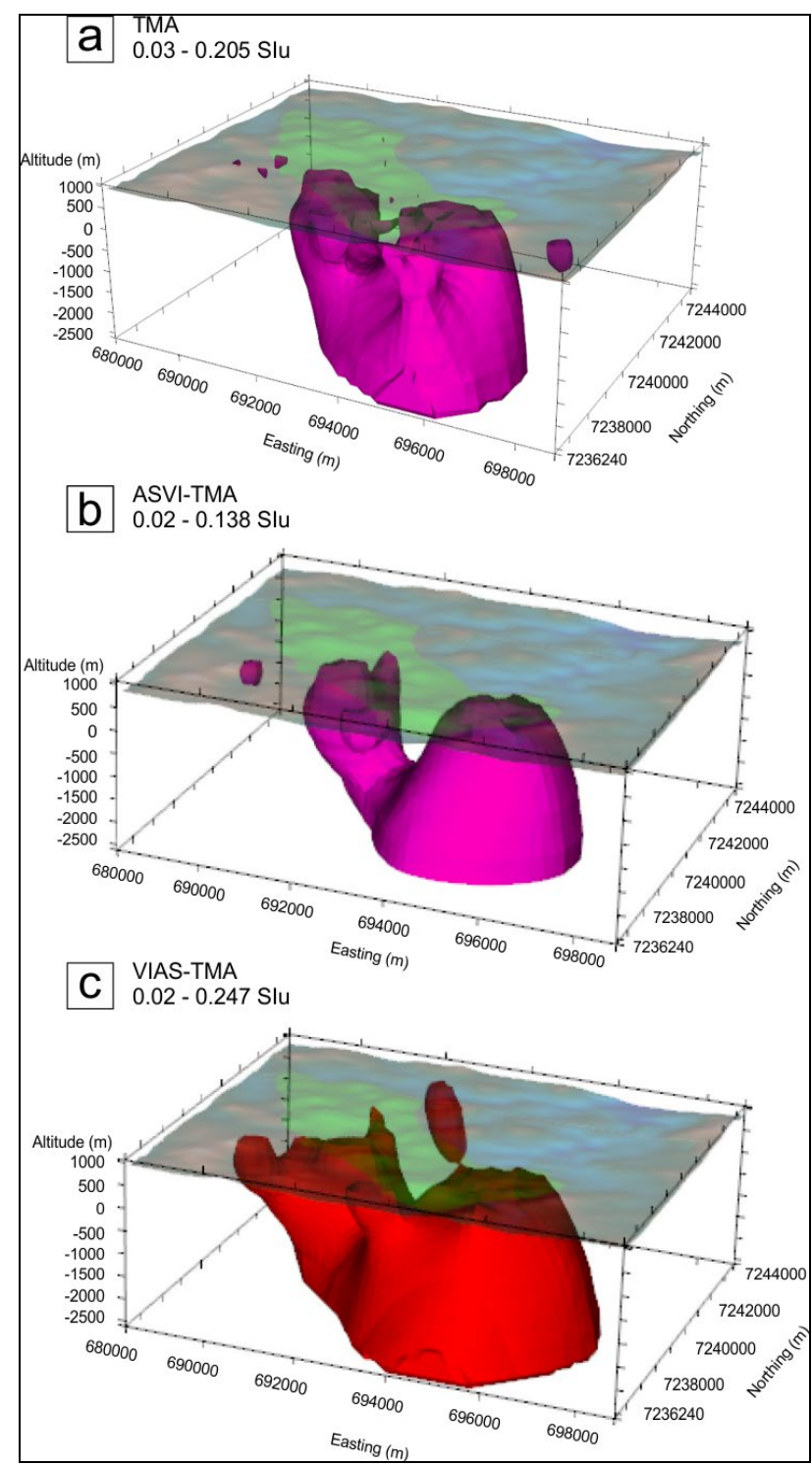

Figure 9. Contrast of apparent magnetic susceptibility distribution in $3 D$ models for each type of Tunas Complex gridded data described in Fig. 8 (except for the RTP-TMA grid). Models were cut in an arbitrary threshold value (displayed on the image) to create a better representation of the surface geology. Altitudes are GPS altitudes and zero values correspond to the Mean Sea Level (MSL). The blue and brown colored grid over the top represents the Digital Terrain Model (DTM) for the area, which ranges from 1049 to $681 \mathrm{~m}$. The green polygon represents the Tunas Complex geologic surface boundaries. 